\title{
Fluorescent Membrane Probes Based on a Coumarin-Thiazole Scaffold
}

\author{
Stane Pajk, ${ }^{1,2, *}$ Maja Garvas ${ }^{2,3}$ and Janez Štrancar ${ }^{2}$ \\ ${ }^{1}$ Faculty of pharmacy, University of Ljubljana, Ljubljana, Slovenia \\ ${ }^{2}$ Laboratory of biophysics, Jožef Stefan Institute, Ljubljana, Slovenia \\ ${ }^{3}$ Jožef Stefan International Postgraduate School, Ljubljana, Slovenia \\ * Corresponding author: E-mail: stane.pajk@ffa.uni-lj.si
}

Received: 02-28-2019

\begin{abstract}
Biological functions of cell membranes and their correlation to the heterogeneity of the latter's lipid composition are still poorly understood. Fluorescence provides one of the most versatile tools for studying biological membranes. However, few bright and photostable fluorescent probes for labeling plasma membranes are available. We have designed and synthesized two such probes, $\mathbf{8}$ and $\mathbf{9}$, that are based on the thiazole-coumarin scaffold. Both are environment sensitive and exhibit similar shifts of emission spectra in a variety of solvents as probes based on 7-nitrobenz-2-oxa-1,3-diazol-4-yl (NBD). In particular, the second, positively charged probe 9 labels the plasma membrane selectively with limited redistribution to other membranes of the cell. Unfortunately, compared to the other two probes tested, 8 and 6-NBD-PC, it exhibits the highest rate of photobleaching. Nevertheless, these new thiazole-coumarin based membrane probes provide a viable approach to the design of novel membrane probes.
\end{abstract}

Keywords: Fluorophore; microscopy; coumarin; photobleaching; membrane

\section{Introduction}

The biological functions of cell membranes are strongly related to the heterogeneity of their lipid composition. ${ }^{1}$ However, the underlying mechanisms responsible for membrane heterogeneity remain poorly understood and are therefore a hot topic of research. ${ }^{1}$ Membrane heterogeneity is essentially that of lipid distribution, identifiable by distinct physicochemical properties measurable by an array of techniques. ${ }^{2}$ Fluorescence techniques stand out of this array, because of their high sensitivity and ability to operate in systems of varied complexity. ${ }^{2}$ Because of this advantages fluorescence techniques became practically indispensable in the fields relevant to physical, chemical, biological and medical sciences. ${ }^{3}$

Especially fluorescence microscopy techniques revolutionized our understanding of life at cellular level. With appropriate probes we are able to visualize selected structures, view on-going processes or measure numerous parameters e.g. intracellular concentration of a selected ion..$^{3-5}$ However, new technologies based on fluorescence phenomena continually emerge, while the development of new fluorophores and fluorescent probes lags behind. ${ }^{6}$ This problem is especially pronounced in fluorescence imaging of membranes in live cells, since not many suitable membrane probes are available. Although most of such probes work well in model membranes, they are frequently unsuitable for experiments on living cells, because, for example, of their internalization, photobleaching and toxicity. ${ }^{7}$

Differences in lipid composition are reflected in small differences in polarity of the membrane. The latter can be detected by solvatochromic dyes, a subclass of environment-sensitive probes. ${ }^{7}$ In principle, environment-sensitive probes do not need selective partitioning in the membrane, since changes in local polarity result in changes of quantum yield and shifts of their emission maxima. ${ }^{7}$ The latter can be observed by several fluorescence microspectroscopy techniques (spectral imaging) that enable very small shifts of emission maximum position, down to $1 \mathrm{~nm}$, to be detected. ${ }^{8}$

7-Nitrobenz-2-oxa-1,3-diazol-4-yl (NBD) is one of the environment-sensitive fluorophores widely used for studying membrane heterogeneity (Figure 1, A). However, it has a number of downsides, photobleaching being one of the most pronounced. ${ }^{9,10}$ Fluorophores based on the cou- 

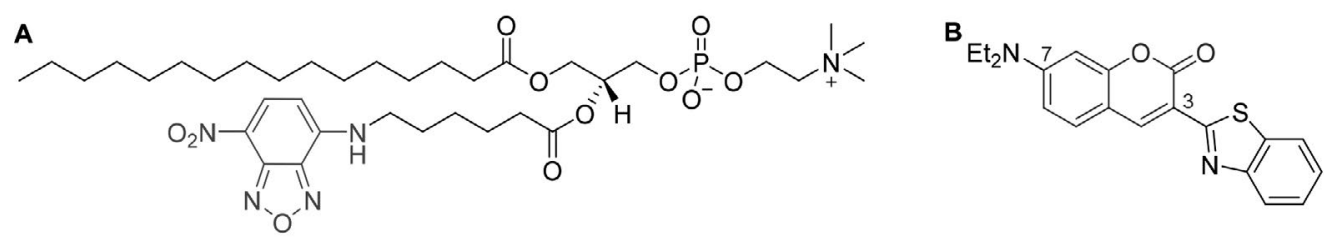

Figure 1. (A) Structure of the phospholipid analog C6-NBD-PC, $N$-(7-nitrobenz-2-oxa-1,3-diazol-4-yl (NBD) is in green. (B) Coumarin 6 dye with coumarin scaffold highlighted in blue and with marked positions 3 and 7.

marin scaffold (Figure 1, B) are also environment sensitive and, usually, more photostable than NBD. ${ }^{11}$ Moreover, there are well established structure-spectra relationships that enable the design of coumarin-based probes with predictable photophysical properties. ${ }^{12}$

In this work, we report on the synthesis of two fluorescent membrane probes based on the coumarin-thiazole scaffold. The aim was to produce probes for selective labeling of plasma membranes of living cells. The synthesized probes were compared to 6-NBD-PC regarding labeling properties, environment-sensitivity and photostability.

\section{Experimental}

\section{1. Materials and Methods}

Chemicals from Sigma-Aldrich and Acros were used without further purification. All reactions were performed under argon atmosphere unless otherwise stated. Analytical TLC was performed on Merck silica gel $\left(60 \mathrm{~F}_{254}\right)$ plates $(0.25 \mathrm{~mm})$ and visualized with ultraviolet light and detected with $20 \%$ sulphuric acid in ethanol. Melting points were determined on a Reichert hot stage microscope. ${ }^{1} \mathrm{H}$ and ${ }^{13} \mathrm{C}$ NMR spectra were recorded on a BRUKER AVANCE III $400 \mathrm{MHz}$ NMR spectrometer in $\mathrm{CDCl}_{3}, \mathrm{DMSO}-d_{6}$, $\mathrm{MeOH}-d_{4}$, and pyridine- $d_{5}$ solution, with TMS or residual solvent signals as the internal standards. Mass spectra were recorded using an ADVION expression CMS and a VG-Analytical Q-TOF Premier mass spectrometer, the later for determination of high resolution masses (HRMS). Fluorescence spectra were measured with Perkin Elmer LS 55 fluorescence spectrophotometer or Biotec Synergy H4 Hybrid Microplate reader. Absorption spectra were measured with Varian Cary 50 UV-Vis spectrophotometer. Inverted Nikon TE-2000 E fluorescence microscope, equipped with a confocal unit Carv II (BD Biosciences) and Rolera-MGi camera was used for fluorescence microscopy observations.

\section{2. Synthesis and Characterization}

3-(Benzyloxy)- $N, N$-dioctylaniline (1). An oven-dried pressure tube equipped with a magnetic stirring bar was charged with $\mathrm{Pd}_{2} \mathrm{dba}_{3}$ (69.6 mg, $1 \mathrm{~mol} \%$ ), RuPhos (35.4 mg, $1 \mathrm{~mol} \%)$, KOtBu (1.53 g, $13.7 \mathrm{mmol}, 1.8$ equiv.), 1-(benzyloxy)-3-bromobenzene ( $2 \mathrm{~g}, 7.6 \mathrm{mmol}, 1$ equiv.) and activated molecular sieves of $4 \AA$ ( $300 \mathrm{mg})$. The vessel was flushed well with argon. Dry toluene $(10 \mathrm{~mL})$ and di- octylamine (3.2 mL, 1.4 equiv.) were added, and the pressure tube was sealed with a Teflon screw cap and placed into an oil bath at $110^{\circ} \mathrm{C}$ for $3 \mathrm{~h}$. The reaction mixture was then cooled to room temperature and filtered. The solvent was removed under reduced pressure and the crude product was purified by flash chromatography (EtOAc:hexane, 1:6), to give the desired product (95\%) as a light yellow oil. ${ }^{1} \mathrm{H} \mathrm{NMR}\left(400 \mathrm{MHz}, \mathrm{CDCl}_{3}\right): \delta(\mathrm{ppm}) 7.49-7.28(\mathrm{~m}, 5 \mathrm{H})$, $7.10\left(\mathrm{dd}, J_{1,2}=8.0 \mathrm{~Hz}, 1 \mathrm{H}\right), 6.30-6.22(\mathrm{~m}, 2 \mathrm{H}), 5.04(\mathrm{~s}$, $2 \mathrm{H}), 3.25-3.15(\mathrm{~m}, 4 \mathrm{H}), 1.60-1.48(\mathrm{~m}, 4 \mathrm{H}), 1.35-1.15(\mathrm{~m}$, $20 \mathrm{H}), 0.88(\mathrm{t}, J=8.0 \mathrm{~Hz}, 6 \mathrm{H}) .{ }^{13} \mathrm{C} \mathrm{NMR}\left(100 \mathrm{MHz}, \mathrm{CDCl}_{3}\right)$ : $\delta 160.31,149.68,137.66,129.92,128.69,127.95,127.66$, $105.24,100.85,99.14,70.02,51.26,31.99,29.66,29.50$, 27.41, 27.33, 22.81, 14.26. MS (ESI): $m / z$ calcd. for $\mathrm{C}_{29} \mathrm{H}-$ ${ }_{46} \mathrm{NO}: 424.3(\mathrm{M}+\mathrm{H})^{+}$, found 424.1 .

3-(Dioctylamino)phenol (2). Compound 1 (3.26g, 7.7 mmol) was dissolved in EtOAc (100 mL). Argon was passed through the solution, followed by addition of Pd/C (350 $\mathrm{mg}$ ). Hydrogen was passed through the reaction mixture and the reaction mixture was than stirred at room temperature with hydrogen atmosphere for $15 \mathrm{~h}$. Argon was passed through the reaction mixture, $\mathrm{Pd} / \mathrm{C}$ was filtered off and the solvent was removed under reduced pressure, to yield the desired product as dark oil (99\%). The crude product was used in the next step without further purification. MS (ESI): $m / z$ calcd. for $\mathrm{C}_{22} \mathrm{H}_{38} \mathrm{NO}: 332.3[\mathrm{M}-\mathrm{H}]^{-}$, found 332.2.

4-(Dioctylamino)-2-hydroxybenzaldehyde (3). $\mathrm{POCl}_{3}$ (1.26 mL, $13.5 \mathrm{mmol}, 3$ equiv.) was added dropwise to dry DMF $(3 \mathrm{~mL})$ at $0{ }^{\circ} \mathrm{C}$ (ice bath). Reaction mixture was stirred on an ice bath for 30 minutes, followed by dropwise addition of phenol 2 dissolved in dry DMF ( $2 \mathrm{~mL})$. Reaction mixture was than stirred at $80{ }^{\circ} \mathrm{C}$ for $2 \mathrm{~h}$. Reaction mixture was cooled to room temperature, diluted with EtOAc $(50 \mathrm{~mL})$ and transferred to a flask with saturated solution of $\mathrm{NaHCO}_{3}(100 \mathrm{~mL})$. The mixture was stirred for $1 \mathrm{~h}$ at room temperature. Upper organic layer was collected, washed with brine $(50 \mathrm{~mL})$ and dried over $\mathrm{Na}_{2} \mathrm{SO}_{4}$. The solvent was evaporated under reduced pressure and the crude product was purified by flash chromatography (DCM), to give the desired product (41\%) as light brown oil. ${ }^{1} \mathrm{H}$ NMR (400 MHz, $\left.\mathrm{CDCl}_{3}\right): \delta(\mathrm{ppm}) 11.65(\mathrm{~s}, 1 \mathrm{H})$, $9.48(\mathrm{~d}, J=0.4 \mathrm{~Hz}, 1 \mathrm{H}), 7.25(\mathrm{~d}, J=8.8 \mathrm{~Hz}, 1 \mathrm{H}), 6.22\left(\mathrm{dd}, J_{1}\right.$ $\left.=8.8 \mathrm{~Hz}, J_{2}=1.6 \mathrm{~Hz}, 1 \mathrm{H}\right), 6.03(\mathrm{~s}, J=1.6 \mathrm{~Hz}, 1 \mathrm{H}), 3.35-3.25$ $(\mathrm{m}, 4 \mathrm{H}), 1.66-1.50(\mathrm{~m}, 4 \mathrm{H}), 1.37-1.20(\mathrm{~m}, 20 \mathrm{H}), 0.89(\mathrm{t}, J$ $=8.0 \mathrm{~Hz}, 6 \mathrm{H}) \cdot{ }^{13} \mathrm{C} \mathrm{NMR}\left(100 \mathrm{MHz}, \mathrm{CDCl}_{3}\right): \delta(\mathrm{ppm})$ 
191.97, 164.39, 154.57, 135.38, 111.51, 104.75, 97.01, 51.42, $31.90,29.52,29.38,27.37,27.13,22.75,14.21$. MS (ESI): $m / z$ calcd. for $\mathrm{C}_{23} \mathrm{H}_{40} \mathrm{NO}_{2}: 362.3[\mathrm{M}+\mathrm{H}]^{+}$, found 362.2.

\section{7-(Dioctylamino)-2-oxo-2H-chromene-3-carboxamide} (4). The aldehyde 3 (643 mg, $1.8 \mathrm{mmol}, 1$ equiv.) and diethylmalonate $(822 \mu \mathrm{L}, 4.5 \mathrm{~mol}, 2.5$ equiv.) was dissolved in dry ethanol $(30 \mathrm{~mL})$ followed by the addition of piperidine ( $50 \mu \mathrm{L}, 0.5 \mathrm{~mol}, 0.28$ equiv.). Reaction mixture was refluxed for $15 \mathrm{~h}$. Methanol $(20 \mathrm{~mL})$ was added to cooled $\left(0{ }^{\circ} \mathrm{C}\right)$ reaction mixture and ammonia gas was bubbled through for $15 \mathrm{~min}$. Yellow precipitate started to form and the reaction mixture was stirred at room temperature for 3 days. Water $(20 \mathrm{~mL})$ was added to the reaction mixture and the desired product was collected by filtration as a yellow precipitate (87\%). M.p. $90-93{ }^{\circ} \mathrm{C} .{ }^{1} \mathrm{H}$ NMR $(400 \mathrm{MHz}$, DMSO- $\left.d_{6}\right): \delta(\mathrm{ppm}) 8.66(\mathrm{~s}, 1 \mathrm{H}), 8.02(\mathrm{~d}, J=3.6 \mathrm{~Hz}, 1 \mathrm{H})$, $7.66(\mathrm{~d}, J=8.8 \mathrm{~Hz}, 1 \mathrm{H}), 7.61(\mathrm{~d}, J=3.6 \mathrm{~Hz}, 1 \mathrm{H}), 6.77(\mathrm{dd}$, $\left.J_{1}=8.8 \mathrm{~Hz}, J_{2}=2.4 \mathrm{~Hz}, 1 \mathrm{H}\right), 6.56(\mathrm{~d}, J=2.4 \mathrm{~Hz}, 1 \mathrm{H}), 3.46-$ $3.34(\mathrm{~m}, 4 \mathrm{H}), 1.60-1.48(\mathrm{~m}, 4 \mathrm{H}), 1.38-1.20$ (m, 20H), 0.86 $(\mathrm{t}, J=6.8 \mathrm{~Hz}, 6 \mathrm{H}) \cdot{ }^{13} \mathrm{C} \mathrm{NMR}\left(100 \mathrm{MHz}, \mathrm{DMSO}-d_{6}\right): \delta$ (ppm) 163.64, 161.70, 157.34, 152.83, 148.10, 131.51, $110.19,109.65,107.65,95.95,50.36,31.25,28.84,28.73$, $26.74,26.23,22.10,13.96$. MS (ESI): $m / z$ calcd. for $\mathrm{C}_{26} \mathrm{H}-$ ${ }_{40} \mathrm{~N}_{2} \mathrm{O}_{3} \mathrm{Na}: 451.3[\mathrm{M}+\mathrm{Na}]^{+}$, found 451.0.

7-(Dioctylamino)-2-oxo-2H-chromene-3-carbothioamide (5). The amide 4 (609 $\mathrm{mg}, 1.9 \mathrm{mmol}, 1$ equiv.) and Lawesson's reagent ( $395 \mathrm{mg}, 0.98 \mathrm{mmol}, 0.51$ equiv.) were dissolved in dry dioxane $(20 \mathrm{~mL})$ and the reaction mixture was refluxed overnight. The solvent was evaporated under reduced pressure and the residue dissolved in EtOAc (50 $\mathrm{mL})$. EtOAc solution was washed with water $(2 \times 50 \mathrm{~mL})$, saturated aqueous solution of $\mathrm{NaHCO}_{3}(2 \times 50 \mathrm{~mL})$, brine $(50 \mathrm{~mL})$ and dried over $\mathrm{Na}_{2} \mathrm{SO}_{4}$. The solvent was evaporated under reduced pressure and the crude product was purified by flash chromatography (EtOAc:hexane, 1:2), to give the desired product (61\%) as a brown solid. ${ }^{1} \mathrm{H}$ NMR $\left(400 \mathrm{MHz}, \mathrm{CDCl}_{3}\right): \delta(\mathrm{ppm}) 10.37(\mathrm{~d}, J=5.6 \mathrm{~Hz}, 1 \mathrm{H}), 9.32$ (s, $1 \mathrm{H}), 7.92(\mathrm{~d}, J=5.6 \mathrm{~Hz}, 1 \mathrm{H}), 7.47(\mathrm{~d}, J=9.2 \mathrm{~Hz}, 1 \mathrm{H})$, $6.64\left(\mathrm{dd}, J_{1}=9.2 \mathrm{~Hz}, J_{2}=2.4 \mathrm{~Hz}, 1 \mathrm{H}\right), 6.44(\mathrm{~d}, J=2.4 \mathrm{~Hz}$, $1 \mathrm{H}), 3.45-3.32(\mathrm{~m}, 4 \mathrm{H}), 1.70-1.56(\mathrm{~m}, 4 \mathrm{H}), 1.40-1.22(\mathrm{~m}$, $20 \mathrm{H}), 0.89(\mathrm{t}, J=7.2 \mathrm{~Hz}, 6 \mathrm{H})$. MS (ESI): $m / z$ calcd. for $\mathrm{C}_{26} \mathrm{H}_{40} \mathrm{~N}_{2} \mathrm{O}_{2} \mathrm{SNa}$ : $467.3[\mathrm{M}+\mathrm{Na}]^{+}$, found 467.2.

3-(4-(Chloromethyl)thiazol-2-yl)-7-(dioctylamino)2H-chromen-2-one (6). The thioamide 5 (515 mg, 1.16 mmol, 1 equiv.) was dissolved in DMF $(5 \mathrm{~mL})$, followed by addition of 1,3-dichloropropan-2-one (177 mg, $1.4 \mathrm{mmol}$, 1.2 equiv.). The reaction mixture was stirred at room temperature for 3 days. Solvent was removed under reduced pressure and the residue was dissolved in DCM $(50 \mathrm{~mL})$, washed with saturated solution of $\mathrm{NaHCO}_{3}(2 \times 30 \mathrm{~mL})$, water $(2 \times 30 \mathrm{~mL})$ and brine $(2 \times 50 \mathrm{~mL})$, and dried over $\mathrm{Na}-$ ${ }_{2} \mathrm{SO}_{4}$. The solvent was evaporated under reduced pressure and the crude product was purified by flash chromatogra- phy (DCM), to give the desired product (69\%) as an orange solid. M.p. $57-60{ }^{\circ} \mathrm{C} .{ }^{1} \mathrm{H} \mathrm{NMR}\left(400 \mathrm{MHz}, \mathrm{CDCl}_{3}\right): \delta$ (ppm) $8.23(\mathrm{~s}, 1 \mathrm{H}), 7.43(\mathrm{~d}, J=8.8 \mathrm{~Hz}, 1 \mathrm{H}), 7.35(\mathrm{~s}, 1 \mathrm{H})$, $6.62\left(\mathrm{dd}, J_{1}=8.8 \mathrm{~Hz}, J_{2}=2.4 \mathrm{~Hz}, 1 \mathrm{H}\right), 6.51(\mathrm{~d}, J=2.4 \mathrm{~Hz}$, $1 \mathrm{H}), 4.75(\mathrm{~d}, J=0.8 \mathrm{~Hz}, 2 \mathrm{H}), 3.35(\mathrm{t}, J=8.0 \mathrm{~Hz}, 4 \mathrm{H}), 1.68-$ $1.56(\mathrm{~m}, 4 \mathrm{H}), 1.40-1.22(\mathrm{~m}, 20 \mathrm{H}), 0.89(\mathrm{t}, J=6.8 \mathrm{~Hz}, 6 \mathrm{H})$. ${ }^{13} \mathrm{C} \mathrm{NMR}\left(100 \mathrm{MHz}, \mathrm{CDCl}_{3}\right): \delta$ (ppm) 161.81, 161.09, $156.63,152.20,151.71,140.53,130.47,118.81,118.79$, $112.32,110.10,108.50,97.16,97.14,51.55,41.26,31.88$, 29.52, 29.38, 27.29, 27.13, 22.74, 14.20. MS (ESI): $\mathrm{m} / z$ calcd. for $\mathrm{C}_{29} \mathrm{H}_{41} \mathrm{ClN}_{2} \mathrm{O}_{2} \mathrm{SNa}$ : $539.3[\mathrm{M}+\mathrm{Na}]^{+}$, found 539.0.

Diethyl ((2-(7-(dioctylamino)-2-oxo-2H-chromen-3-yl) thiazol-4-yl)methyl)phosphonate (7). Thiazol 6 (206 mg, $0.4 \mathrm{mmol}, 1.1$ equiv.) was dissolved in triethyl phosphite (3 $\mathrm{mL}$ ) and the solution was stirred at $130^{\circ} \mathrm{C}$ for $15 \mathrm{~h}$. Triethyl phosphite was distilled off under reduced pressure and the crude product was purified by flash chromatography (DCM:MeOH, 50:1 to 25:1), to give the desired product (81\%) as an orange oil. ${ }^{1} \mathrm{H}$ NMR $\left(400 \mathrm{MHz}, \mathrm{CDCl}_{3}\right): \delta$ (ppm) $8.69(\mathrm{~s}, 1 \mathrm{H}), 7.42(\mathrm{~d}, J=8.8 \mathrm{~Hz}, 1 \mathrm{H}), 7.29-7,26$ $(\mathrm{m}, 1 \mathrm{H}), 6.62\left(\mathrm{dd}, J_{1}=8.8 \mathrm{~Hz}, J_{2}=2.4 \mathrm{~Hz}, 1 \mathrm{H}\right), 6.51(\mathrm{~d}, J=$ $2.4 \mathrm{~Hz}, 1 \mathrm{H}), 4.15-4.05(\mathrm{~m}, 4 \mathrm{H}), 3.46(\mathrm{~d}, J=21.2 \mathrm{~Hz}, 2 \mathrm{H})$, $3.40-3.29$ (m, 4H), 1.69-1.55 (m, 4H), 1.42-1.19 (m, 26H), $0.98-0.81(\mathrm{~m}, 6 \mathrm{H}) .{ }^{13} \mathrm{C} \mathrm{NMR}\left(100 \mathrm{MHz}, \mathrm{CDCl}_{3}\right): \delta(\mathrm{ppm})$ $161.11,160.48,156.55,152.05,146.22\left(\mathrm{~d},{ }^{2} J_{\mathrm{P}, \mathrm{C}}=8.0 \mathrm{~Hz}\right)$, $140.03,130.31,117.79\left(\mathrm{~d},{ }^{3} J_{\mathrm{P}, \mathrm{C}}=7.2 \mathrm{~Hz}\right), 112.79,110.03$, $108.59,97.22,62.38\left(\mathrm{~d},{ }^{2} J_{\mathrm{P}, \mathrm{C}}=6.6 \mathrm{~Hz}\right), 51.55,31.89,29.80$ $\left(\mathrm{d},{ }^{1} J_{\mathrm{P}, \mathrm{C}}=140.6 \mathrm{~Hz}\right), 29.38,29.10,27.30,27.15,22.74,16.52$ $\left(\mathrm{d},{ }^{3} J_{\mathrm{P}, \mathrm{C}}=6.1 \mathrm{~Hz}\right), 14.21$. HRMS (ESI): $m / z$ calcd. for $\mathrm{C}_{33} \mathrm{H}-$ ${ }_{52} \mathrm{~N}_{2} \mathrm{O}_{5}$ PS: $619.3335[\mathrm{M}-\mathrm{H}]^{-}$, found 619.3346.

((2-(7-(Dioctylamino)-2-oxo-2H-chromen-3-yl)thiazol4-yl)methyl)phosphonic acid (8). To a solution of diethyl phosphonat 7 (190 mg, $0.31 \mathrm{mmol}, 1$ equiv.) in dry $\mathrm{CH}_{2} \mathrm{Cl}_{2}$ $(7.5 \mathrm{~mL})$ cooled in an ice bath, TMSBr $(1.5 \mathrm{~mL})$ was added dropwise. The reaction mixture was left to react for 3 days at room temperature. The solvent was evaporated under reduced pressure and $5 \mathrm{~mL}$ of a mixture of THF and water (1:1) was added and the reaction mixture was stirred for 1 day. Solvents were removed under reduced pressure and product was re-crystalized from $\mathrm{CH}_{3} \mathrm{CN}$ to give an orange solid (84\%). M.p. $106-109{ }^{\circ} \mathrm{C} .{ }^{1} \mathrm{H}$ NMR $(400 \mathrm{MHz}$, pyridine- $\left.d_{5}\right): \delta(\mathrm{ppm}) 8.89(\mathrm{~s}, 1 \mathrm{H}), 7.78(\mathrm{~d}, J=3.2 \mathrm{~Hz}, 1 \mathrm{H}), 7.54$ $(\mathrm{d}, J=9.2 \mathrm{~Hz}, 1 \mathrm{H}), 6.82\left(\mathrm{dd}, J_{1}=9.2 \mathrm{~Hz}, J_{2}=1.6 \mathrm{~Hz}, 1 \mathrm{H}\right)$, $6.65(\mathrm{~d}, J=1.6 \mathrm{~Hz}, 1 \mathrm{H}), 4.02(\mathrm{~d}, J=20.4 \mathrm{~Hz}, 2 \mathrm{H}), 3.37(\mathrm{t}, J=$ $7.6 \mathrm{~Hz}, 4 \mathrm{H}), 1.67-1.54(\mathrm{~m}, 4 \mathrm{H}), 1.35-1.15(\mathrm{~m}, 20 \mathrm{H}), 0.87(\mathrm{t}$, $J=7.2 \mathrm{~Hz}, 6 \mathrm{H}) .{ }^{13} \mathrm{C} \mathrm{NMR}\left(100 \mathrm{MHz}\right.$, pyridine- $\left.d_{5}\right): \delta(\mathrm{ppm})$ $161.21,160.11,157.17,152.67,151.15\left(\mathrm{~d},{ }^{2} J_{\mathrm{P}, \mathrm{C}}=7.6 \mathrm{~Hz}\right)$, $140.42,131.13,117.93\left(\mathrm{~d},{ }^{3} J_{\mathrm{P}, \mathrm{C}}=6.3 \mathrm{~Hz}\right), 113.48,110.84$, $109.15,97.52,51.63,33.76\left(\mathrm{~d},{ }^{1} J_{\mathrm{P}, \mathrm{C}}=134.0 \mathrm{~Hz}\right), 32.34,30.01$, 29.87, 27.83, 27.49, 23.23, 14.60. HRMS (ESI): $\mathrm{m} / z$ calcd. for $\mathrm{C}_{29} \mathrm{H}_{44} \mathrm{~N}_{2} \mathrm{O}_{5}$ PS: $563.2709[\mathrm{M}+\mathrm{H}]^{+}$, found 563.2705.

1-(2-(7-(Dioctylamino)-2-oxo-2H-chromen-3-yl)thiazol-4-yl)- $N, N, N$-trimethylmethanaminium chloride 
(9). Compound 6 (106 mg, $0.20 \mathrm{mmol}, 1$ equiv.) was dissolved in $4.2 \mathrm{M}$ solution of trimethylamine $(5 \mathrm{~mL})$. The reaction mixture was left to react for 3 days at room temperature. The solvent was evaporated under reduced pressure and the solid residue was suspended in a mixture of diethyl ether and hexane (1:1) (5 mL), filtered and washed with diethyl ether and hexane $(1: 1)(10 \mathrm{~mL})$, to give the desired product as an orange solid (85\%). M.p. 152-155 ${ }^{\circ} \mathrm{C} .{ }^{1} \mathrm{H}$ NMR (400 MHz, MeOD): $\delta$ (ppm) $8.73(\mathrm{~s}, 1 \mathrm{H})$, $7.89(\mathrm{~s}, 1 \mathrm{H}), 7.52(\mathrm{~d}, J=9.2 \mathrm{~Hz}, 1 \mathrm{H}), 6.75\left(\mathrm{dd}, J_{1}=9.2 \mathrm{~Hz}\right.$, $\left.J_{2}=1.6 \mathrm{~Hz}, 1 \mathrm{H}\right), 6.51(\mathrm{~d}, J=1.6 \mathrm{~Hz}, 1 \mathrm{H}), 4.70(\mathrm{~s}, 2 \mathrm{H}), 3.42$ $(\mathrm{t}, J=7.6 \mathrm{~Hz}, 4 \mathrm{H}), 3.25(\mathrm{~s}, 9 \mathrm{H}), 1.72-1.58(\mathrm{~m}, 4 \mathrm{H}), 1.45-$ $1.25(\mathrm{~m}, 20 \mathrm{H}), 0.90(\mathrm{t}, J=7.2 \mathrm{~Hz}, 6 \mathrm{H}) .{ }^{13} \mathrm{C}$ NMR $(100$ MHz, MeOD): $\delta$ (ppm) 164.03, 162.66, 158.19, 154.35, $145.04,142.61,132.20,127.05,112.54,111.93,109.77$, $97.92,65.45,54.03,52.38,33.15,30.73,30.61,28.45,28.14$, 23.89, 14.61. HRMS (ESI): $\mathrm{m} / z$ calcd. for $\mathrm{C}_{32} \mathrm{H}_{50} \mathrm{~N}_{3} \mathrm{O}_{2} \mathrm{~S}$ : $540.3624[\mathrm{M}]^{+}$, found 540.3637 .

\section{3. Cell Culture and Parameters of Fluorescence Microscopy}

Mouse lung epithelial cell line LA-4 was cultured in cell medium (F12K medium, 15\% FCS, both from ATCC, $1 \% \mathrm{P} / \mathrm{S}$ (antibiotics), 1\% NEAA (nonessential amino acids) from Sigma). The cells were cultured at $37^{\circ} \mathrm{C}$ in a humidified $5 \% \mathrm{CO}_{2}$ atmosphere. For the fluorescence microscopy observation, cells were plated on 8 well glass-bottom cell culture dish (Lab-Tek Chambred Coverglass) for an additional day. Cell medium was replaced with fluorescent dye in a phosphate buffer saline at final concentration $10^{-7} \mathrm{M}$ or $10^{-8} \mathrm{M}(0.1 \% \mathrm{DMSO})$, incubated for a few minutes than fluorescence at different time points was measured or wide field fluorescence images were taken. Samples were excited by nonpolarized light from a Xe-Hg source (Sutter Lambda LS, Novato, CA) through broad-band filters (all band-pass filters and dichroic were BrightLine from Semrock, Rochester, NY). Fluorescence was detected through matching broadband filters. Objective with $60 \times$ (water immersion) magnification was used with high numerical aperture (NA $=1.27$, working distance $0.17 \mathrm{~mm}$ ). Set of filters used in experiments was following: $415-455 \mathrm{~nm}$ excitation filter, 458 $\mathrm{nm}$ dichroic, and 468-552 $\mathrm{nm}$ emission filter.

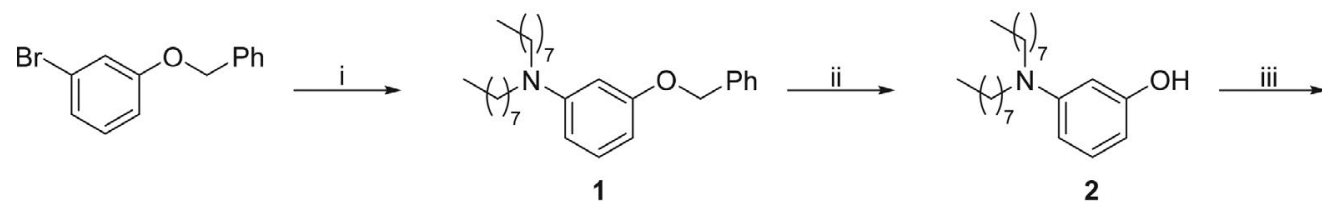

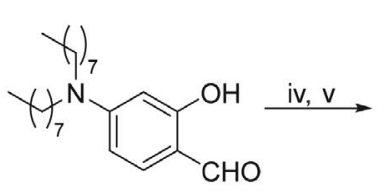

3

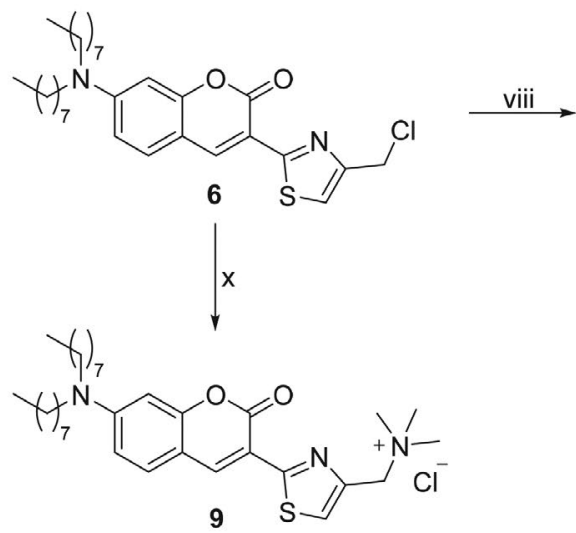

\section{Results and Discussion}

\section{1. Design and Synthesis}

Coumarins have been used as the basis of membrane probes, but the probes presented in this paper are the first 
to mimic the amphiphilic properties of membrane lipids, by possessing aliphatic tails and a polar head incorporated in the coumarin core. ${ }^{13-15}$ Thiazole at position 3 of the coumarin scaffold is known to produce marked red-shifts of the excitation and emission spectra and, in addition, to result in higher molar absorptivities and quantum yields than those of the 3 -unsubstituted derivative. ${ }^{16}$ In our case it also provided the opportunity for introducing a polar head group. ${ }^{17}$ Probes were designed with a permanently charged polar head at physiological $\mathrm{pH}$, since this reduces the likelihood of flip-flop and further redistribution to other membranes of the cell. The lipophilic part of the probe comprises two aliphatic tails attached to the amino group at position 7 of the coumarin scaffold.

Since the synthesized probes differ only in their head groups, the first six synthetic steps were the same for both probes. Synthesis commenced with palladium-catalyzed $\mathrm{N}$-arylation of dioctylamine with 1-(benzyloxy)-3-bromobenzene, giving compound $\mathbf{1}$ in high yield (Scheme 1). ${ }^{18}$ The benzyl protective group was removed with hydrogen in the presence of $\mathrm{Pd} / \mathrm{C}$ to afford compound 2. In the next step, a formyl group was introduced under VilsmeierHaack conditions to yield salicylaldehyde 3 . This was followed by two reaction steps in one pot; first, Knoevenagel condensation between salicylaldehyde $\mathbf{3}$ and diethyl malonate to yield 7-dioctylaminocoumarin-3-carboxylic acid ethyl ester and, second, aminolysis of the ester with ammonia to give amide 4 . The amide 4 was, in the next step and using Lawesson's reagent, converted to thioamide 5. ${ }^{16}$ Reaction between thioamide 5 and 1,3-dichloroacetone in DMF gave thiazole 6 . The latter conversion was first attempted in THF instead of DMF and with the 1.5 equiv. of $\mathrm{Et}_{3} \mathrm{~N}$, as used successfully with aliphatic thioamides, ${ }^{19}$ but the initial attempts did not produce the desired product. Only after replacing the THF by DMF and omitting the base was the desired product, thiazole 6 , obtained. ${ }^{16}$ Thiazole 6 was further reacted with $\mathrm{P}(\mathrm{OEt})_{3}$ to yield diethylphosphonate 7 . In the next step, both ester groups were cleaved with TMSBr to yield probe $\mathbf{8}$ having a negatively charged headgroup. ${ }^{20,21}$ To obtain a probe with a positively charged headgroup, thiazole 6 was reacted with $\mathrm{Me}_{3} \mathrm{~N}$ to give probe $9 .{ }^{22}$

\section{2. Absorption and Emission Spectra}

Absorption spectra of ethanol solutions of probes 8 and 9 were recorded (Figure 2, A). Absorption maximum for probe 8 was $445 \mathrm{~nm}$ and $461 \mathrm{~nm}$ for probe 9 . This is a relatively large difference in position of absorption maxima for probes with the same fluorescent core. To further characterize the photophysical properties, the fluorescence spectra of probes 8 and 9 were recorded in solvents of different polarities (Figure 2, B and C). Shifts in emission maxima and differences in overall shape of spectra in different solvents were more pronounced with probe 8 than with probe $\mathbf{9}$. In the case of probe $\mathbf{8}$, type of solvent also had more significant influence on emission intensity as compared to probe $\mathbf{9}$. Phosphonic acid of probe $\mathbf{8}$ can form hydrogen bonds with the solvent and we assume this is how solvent influences the shape and intensity of emission spectrum. This may also explain the difference in absorption spectra of probes $\mathbf{8}$ and $\mathbf{9}$, since both probes differ only in the type of polar headgroup.

\section{3. Fluorescence Microscopy}

LA4 cells were labeled with probes 8 and 9 and observed under a fluorescence microscope. Labeling was carried out by addition of dyes dissolved in DMSO. Both probes labeled cells rapidly and, at the concentrations used, evenly and without apparent induction of toxicity. Strikingly, probe $\mathbf{8}$ was internalized rapidly into intracellular membranes, whereas probe 9 remained localized mostly on the plasma membrane (Figure 3, A and B). This is in accordance with general observations that positively charged membrane probes are internalized to a lesser extent. ${ }^{7}$ For future development of probe 9 a zwitterion configuration or an additional positive charge at the headgroup should increase localization of the probe at the plasma membrane. ${ }^{7}$
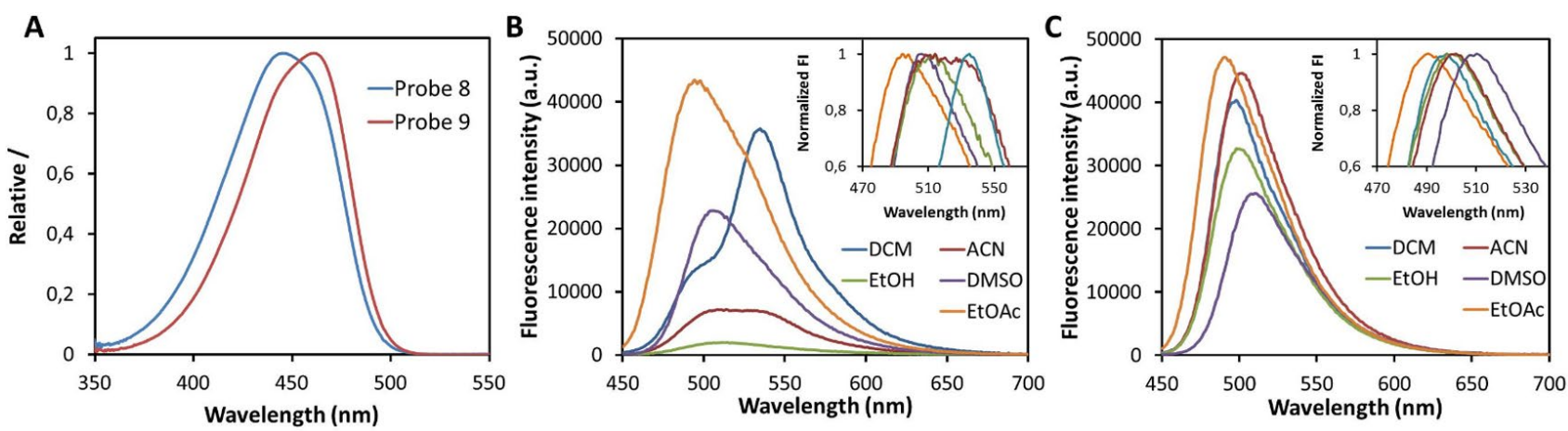

Figure 2. (A) Normalized absorption spectra of probes 8 (blue) and 9 (red). Absorption spectra were recorded with $8 \cdot 10^{-6} \mathrm{M}$ solutions of each in ethanol. (B and C) Emission spectra for probes 8 (B) and 9 (C) in different solvents at concentrations of $5 \cdot 10^{-7} \mathrm{M}\left(\lambda_{\mathrm{ex}}=420 \mathrm{~nm}\right)$. Inset: normalized emission spectra for probes $\mathbf{8}(\mathrm{B})$ and $\mathbf{9}(\mathrm{C})$ in different solvents. 

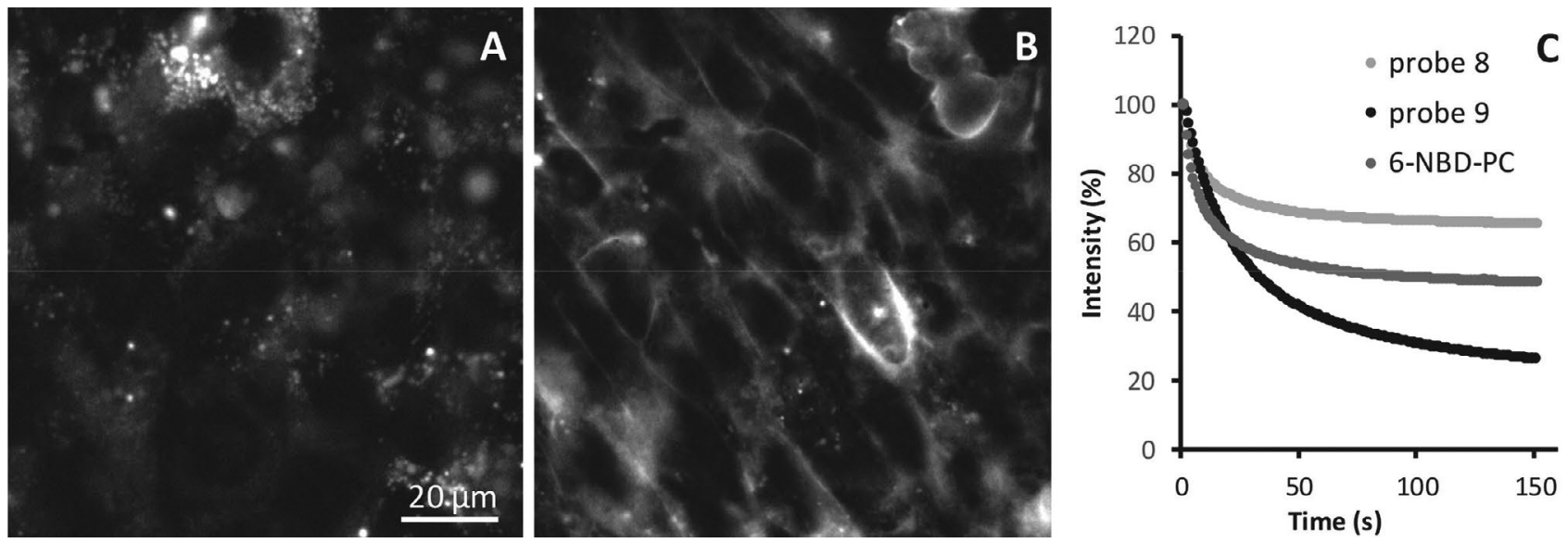

Figure 3. LA4 cells labeled with (A) probe 8 and (B) probe 9 for $5 \mathrm{~min}$ at $10 \mathrm{nM}$ concentration. (C) Bleaching of probes with time; probe $\mathbf{8}$ (light grey circles), probe 9 (black circles) and commercial 6-NBD-PC from Avanti Polar Lipids (dark grey circles). The concentration of the probes on cells, where the bleaching characteristics of probes are presented, was $100 \mathrm{nM}$.

In a study of photostability, probes $\mathbf{8}$ and $\mathbf{9}$ were compared to commercially available 6-NBD-PC in labeled LA4 cells (Figure 3, C). Internalized probe 8 proved to be more photostable than 6-NBD-PC while, surprisingly, probe 9 was more prone to photobleaching than probe 8 or 6-NBD-PC. This is interesting, since probes 8 and 9 possess the same coumarin-thiazole scaffold, differing only in the polar headgroup. As well as small differences in chemical structure, different environment, such as lipid composition, oxygen and antioxidant concentration, can influence the rate of photobleaching. ${ }^{23,24}$ This and the influence of polar headgroup can explain different rates of photobleaching for probes $\mathbf{8}$ and $\mathbf{9}$. The initially planned microspectroscopy, i.e. recording of emission spectra in each voxel, was not possible due to the high rate of photobleaching of probe 9, even when using bleaching-corrected fluorescence microspectroscopy. ${ }^{25}$ This limiting factor will be addressed in any future development by incorporating design features that increase photostability. ${ }^{26,27}$

\section{Conclusion}

The plasma membrane remains in the focus of research, with fluorescent techniques, in particular the numerous types of fluorescence microscopy, being the most versatile tool for its study. The full potential of fluorescence microscopy is, however, limited by the lack of bright and photostable fluorescent probes. We have designed and synthesized two membrane probes, $\mathbf{8}$ and $\mathbf{9}$, both based on the thiazole-coumarin scaffold. Both probes are environment sensitive, especially probe $\mathbf{8}$ exhibits significant shifts of emission maxima and fluorescence intensity depending on the solvent. Both probes quickly labeled cell membranes, in particular, the positively charged probe 9 labeled the plasma membrane selectively, with slow redistribution to other intracellular membranes. Nevertheless, it had the highest rate of photobleaching of all the probes tested, i.e. probes 8 and 6-NBD-PC. Because of the low photostability of probe $\mathbf{9}$, a microspectroscopy study was not possible. However, we have proved that the use of coumarin-based membrane probes constitutes a viable approach to the design of novel membrane probes.

\section{References}

1. E. Sezgin, I. Levental, S. Mayor, C. Eggeling, Nat. Rev. Mol. Cell Biol. 2017, 18, 361-374. DOI:10.1038/nrm.2017.16

2. A. P. Demchenko, Y. Mély, G. Duportail, A. S. Klymchenko, Biophys. J. 2009, 96, 3461-3470.

DOI:10.1016/j.bpj.2009.02.012

3. B. Valeur, J.-C. Brochon (Ed.): New trends in fluorescence spectroscopy: applications to chemical and life science, Springer, New York, 2001. DOI:10.1007/978-3-642-56853-4

4. S. Yuan, W. Su, E. Wang, Acta Chim. Slov. 2017, 64, 638-643. DOI:10.17344/acsi.2017.3442

5. Y. Deng, Y. Chen, X. Zhou, Acta Chim. Slov. 2018, 65, 271277. DOI:10.17344/acsi.2017.3620

6. S. W. Hell, Angew. Chem. 2015, 54, 8054-8066. DOI:10.1002/anie.201504181

7. S. Klymchenko Andrey, R. Kreder, Chem. Biol. 2014, 21, 97113. DOI:10.1016/j.chembiol.2013.11.009

8. Z. Arsov, I. Urbančič, M. Garvas, D. Biglino, A. Ljubetič, T. Koklič, J. Štrancar, Biomed. Opt. Express. 2011, 2, 2083-2095. DOI:10.1364/BOE.2.002083

9. I. Urbančič, A. Ljubetič, Z. Arsov, J. Štrancar, Biophys. J. 2013, 105, 919-927. DOI:10.1016/j.bpj.2013.07.005

10. D. M. C. Ramirez, W. W. Ogilvie, L. J. Johnston, Biochim. Biophys. Acta. 2010, 1798, 558-568.

DOI:10.1016/j.bbamem.2009.12.005

11. S. Pajk, Tetrahedron Lett. 2014, 55, 6044-6047.

DOI:10.1016/j.tetlet.2014.09.019

12. H. Schill, S. Nizamov, F. Bottanelli, J. Bierwagen, V. N. Belov, 
S. W. Hell, Chem. Eur. J. 2013, 19, 16556-16565. DOI:10.1002/chem.201302037

13. C. Wolff, B. Fuks, P. Chatelain, J. Biomol. Screen. 2003, 8, 533543. DOI:10.1177/1087057103257806

14. O. García-Beltrán, O. Yañez, J. Caballero, A. Galdámez, N. Mena, M. T Nuñez, B. K. Cassels, Eur. J. Med. Chem. 2014, 76, 79-86. DOI:10.1016/j.ejmech.2014.02.016

15. P. Jurkiewicz, L. Cwiklik, P. Jungwirth, M. Hof, Biochimie. 2012, 94, 26-32. DOI:10.1016/j.biochi.2011.06.027

16. H. Takechi, Y. Oda, N. Nishizono, K. Oda, M. Machida, Chem. Pharm. Bull. 2000, 48, 1702-1710.

DOI:10.1248/cpb.48.1702

17. N. Nishizono, K. Oda, Y. Kato, K. Ohno, M. Minami, M. Machida, Heterocycles. 2004, 63, 1083-1091.

DOI: $10.3987 / C O M-04-10021$

18. B. P. Fors, S. L. Buchwald, J. Am. Chem. Soc. 2010, 132, 15914-15917. DOI:10.1021/ja108074t

19. S. Pajk, M. Živec, R. Šink, I. Sosič, M. Neu, C. Chung, M. Martínez-Hoyos, E. Pérez-Herrán, D. Álvarez-Gómez, E. Álvarez-Ruíz, A. Mendoza-Losana, J. Castro-Pichel, D. Barros, L. Ballell-Pages, R. J. Young, M. A. Convery, L. Encinas, S. Gobec, Eur. J. Med. Chem. 2016, 112, 252-257.

DOI:10.1016/j.ejmech.2016.02.008

20. K. C. Nicolaou, D. Rhoades, Y. Wang, R. Bai, E. Hamel, M.
Aujay, J. Sandoval, J. Gavrilyuk, J. Am. Chem. Soc. 2017, 139, 7318-7334. DOI:10.1021/jacs.7b02655

21. P. Lassaux, M. Hamel, M. Gulea, H. Delbrück, P. S. Mercuri, L. Horsfall, D. Dehareng, M Kupper, J. Frère, K. Hoffmann, M. Galleni, C. Bebrone, J. Med. Chem. 2010, 53, 4862-4876. DOI:10.1021/jm100213c

22. B. Wang, W. Sun, F. Bu, X. Li, H. Na, C. Zhao, Int. J. Hydrog. Energy. 2016, 41, 3102-3112.

DOI:10.1016/j.ijhydene.2015.12.123

23. O. Woodford, A. Harriman, W. McFarlane, C. Wills, ChemPhotoChem. 2017, 1, 317-325. DOI:10.1002/cptc.201600061

24. C. E. Aitken, R. A. Marshall, J. D. Puglisi., Biophys. J. 2008, 94, 1826-1835. DOI:10.1529/biophysj.107.117689

25. I. Urbančič, Z. Arsov, A. Ljubetič, D. Biglino, J. Štrancar, Opt. Express. 2013, 21, 25291-25306. DOI:10.1364/OE.21.025291

26. J. B. Grimm, B. P. English, J. Chen, J. P. Slaughter, Z. Zhang, A. Revyakin, R. Patel, J. J. Macklin, D. Normanno, R. H. Singer, T. Lionnet, L. D. Lavis, Nat. Methods. 2015, 12, 244-250. DOI: $10.1038 /$ nmeth.3256

27. J. B. Grimm, A. K. Muthusamy, Y. Liang, T. A. Brown, W. C. Lemon, R. Patel, R. Lu, J. J. Macklin, P. J. Keller, N. Ji, L. D. Lavis, Nat. Methods. 2017, 14, 987-994.

DOI: $10.1038 /$ nmeth.4403

\section{Povzetek}

Biološke funkcije celičnih membran in njihove korelacije s heterogenostjo njihove lipidne sestave so še vedno slabo raziskane. Fluorescenca omogoča enega izmed najbolj vsestranskih pristopov k raziskovanju bioloških membran, vendar je za označevanje plazemskih membran na voljo le malo svetlih in fotostabilnih fluorescenčnih označevalcev. Načrtovali in sintetizirali smo dve novi tovrstni fluorescenečni barvili, spojini $\mathbf{8}$ in $\mathbf{9}$, ki temeljita na tiazolo-kumarinskem ogrodju. Obe izkazujeta občutljivost na okolje in kažeta podobne premike v emisijskih spektrih v različnih topilih kot je bilo opaženo pri 7-nitrobenz-2-oksa-1,3-diazol-4-ilu (NBD). Drugo, pozitivno nabito barvilo 9, obarva plazemsko membrano selektivno in $\mathrm{z}$ omejenim prerazporejanjem $\mathrm{v}$ ostale celične membrane. Žal pa 9 , za razliko od preostalih dveh testiranih barvil, torej 8 in 6-NBD-PC, zelo hitro fotobledi. Ne glede na to, razvoj dveh novih tiazolo-kumarinskih membranskih barvil predstavlja smiselen pristop k načrtovanju novih membranskih barvil.

Except when otherwise noted, articles in this journal are published under the terms and conditions of the Creative Commons Attribution 4.0 International License 